Utah State University

DigitalCommons@USU

Ecology Center Publications

Ecology Center

7-11-2019

\title{
Seedling Emergence Patterns of Six Restoration Species in Soils From Two Big Sagebrush Plant Communities
}

\author{
Lacey E. Wilder \\ Utah State University \\ Kari E. Veblen \\ Utah State University \\ Eugene W. Schupp \\ Utah State University \\ Thomas A. Monaco \\ USDA, Agricultural Research Service
}

Follow this and additional works at: https://digitalcommons.usu.edu/eco_pubs

Part of the Ecology and Evolutionary Biology Commons, and the Plant Sciences Commons

\section{Recommended Citation}

Lacey Wilder, Kari E. Veblen, Eugene W. Schupp, and Thomas A. Monaco "Seedling Emergence Patterns of Six Restoration Species in Soils from Two Big Sagebrush Plant Communities," Western North American Naturalist 79(2), 233-246, (11 July 2019). https://doi.org/10.3398/064.079.0209

This Article is brought to you for free and open access by the Ecology Center at DigitalCommons@USU. It has been accepted for inclusion in Ecology Center Publications by an authorized administrator of DigitalCommons@USU.

For more information, please contact

digitalcommons@usu.edu.

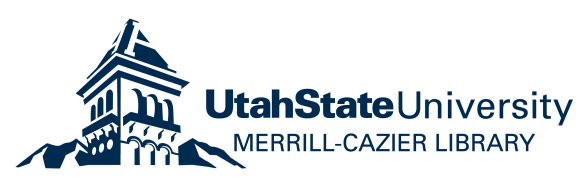




\title{
Seedling emergence patterns of six restoration species in soils from two big sagebrush plant communities
}

\author{
Lacey Wilder ${ }^{1,3}$, Kari E. Veblen ${ }^{1}$, Eugene W. Schupp ${ }^{1}$, and Thomas A. Monaco 2 ,* \\ ${ }^{1}$ Wildland Resources Department and Ecology Center, Utah State University, Logan, UT 84322 \\ 2U.S. Department of Agriculture, Agricultural Research Service, Forage and \\ Range Research Lab, Utah State University, Logan, UT 84322 \\ 3Present address: SWCA Environmental Consultants, Salt Lake City, UT 84111
}

\begin{abstract}
Despite the critical need to improve degraded herbaceous understory conditions in many semiarid ecosystems, the influence of soil properties on seedling emergence of species seeded in shrubland plant communities is largely unexplored. We evaluated emergence patterns of 6 restoration species in soils from wyomingensis (i.e., Wyoming big sagebrush, Artemisia tridentata ssp. wyomingensis [Beetle \& A. Young] S.L. Welsh) and vaseyana (i.e., mountain big sagebrush, A. $t$. ssp. vaseyana [Rydb.] Beetle) plant communities that differed in soil texture, soil organic matter content, and soil water-holding capacity. We conducted 2 separate experiments that regularly wetted soils to standardized soil water potentials (i.e., field capacity; $-0.03 \mathrm{MPa}$ ) and allowed differences in evaporation to create distinct wet-dry watering pattern cycles over a 26-29 d period. Our objectives were to compare soil attributes of wyomingensis and vaseyana soils, evaluate whether emergence patterns of restoration species vary within these soils, and determine how these patterns are altered by soil water-content levels. We found differences in soil texture and organic matter between soils and thus soil water-holding capacity: finer-textured vaseyana soils held roughly twofold more water than coarse-textured wyomingensis soils. Seeds in vaseyana soils were exposed to fewer wet-dry cycles compared to wyomingensis soils because of the greater capacity of vaseyana soils to retain water. Restoration species also collectively exhibited greater emergence in vaseyana soils than in wyomingensis soils, yet emergence patterns were vastly different among species, and differences between soils became more pronounced under low soil water for only 2 species. We conclude that the manner in which soils and water uniquely influenced emergence patterns provides new insights into species suitability for restoration sites and how inherent soil differences may constrain seeding success.
\end{abstract}

Resumen.-A pesar de la necesidad imperante de mejorar las condiciones deterioradas de los sotobosques herbáceos en muchos ecosistemas semiáridos, la influencia que tienen las propiedades del suelo, en la aparición de las plántulas de especies sembradas en las comunidades de matorrales es ampliamente inexplorada. Evaluamos los patrones de emergencia de seis especies en restauración en suelos de comunidades de artemisa wyomingensis (Artemisia tridentata ssp. wyomingensis [Beetle \& A. Young] S.L. Welsh y artemisa vaseyana (A. t. ssp. vaseyana [Rydb.] Beetle), estas comunidades de plantas difirieron en textura, contenido de materia orgánica y capacidad de retención de agua del suelo. Llevamos a cabo dos experimentos separados en los que se humedecieron los suelos regularmente hasta estandarizar su potencial de agua (i.e. capacidad de campo; $-0.03 \mathrm{MPa}$ ), dando lugar a diferencias en la evaporación, con el fin de generar distintos patrones cíclicos de humedad/sequía, durante un período de 26-29 días. Nuestros objetivos fueron (1) comparar los atributos de los suelos de wyomingensis y de vaseyana, (2) evaluar si los patrones de emergencia de las especies en restauración varían entre cada tipo de suelo y (3) determinar cómo estos patrones son alterados por el contenido de agua en el suelo. Encontramos diferencias en la textura y en el contenido de materia orgánica entre los distintos tipos de suelos y, por lo tanto, en su capacidad de retención de agua. La textura fina del suelo de artemisa vaseyana retuvo aproximadamente el doble de agua que el suelo con de textura gruesa de artemisa wyomingensis. Las semillas en los suelos de vaseyana fueron expuestas a menos ciclos humedad/sequía en comparación con él suelo de wyomingensis, debido a la mayor capacidad de retención de agua del suelo de vaseyana. En general, las especies en restauración mostraron mayor recuperación en el suelo de vaseyana que en el de wyomingensis. No obstante, los patrones de recuperación difirieron ampliamente entre las especies. Únicamente en dos especies las diferencias entre el suelo se hicieron más pronunciadas por la escasez de agua en el suelo. Concluimos que la forma en que los suelos y el agua influyen en los patrones de emergencia de las especies, proporciona nueva información acerca de la susceptibilidad de las especies en los sitios de restauración y cómo las características inherentes del tipo de suelo pueden limitar el éxito de la siembra.

*Corresponding author: tom.monaco@ars.usda.gov

$\mathrm{KEV}$ orcid.org/0000-0001-7523-3368

EWS 
The Intermountain Region in the western United States is home to expansive big sagebrush (Artemisia tridentata Nutt.) ecosystems, which occupy an extraordinary variety of environmental conditions (West 1983, Davies et al. 2006). This variety encompasses plant communities in semidesert shrublands, shrub-steppe, and upland foothills and woodlands, as well as high mountain plateaus (West 1988, Miller et al. 2011). Furthermore, big sagebrush plant communities are often dominated, and thus classified, by different subspecies (West 1983, Shultz 2009), with distinct affinities to environmental factors, topographic position, and soils (Davies et al. 2007, Meinke et al. 2009, Chaney et al. 2017). For example, 2 major subspecies-Wyoming big sagebrush (A. $t$. ssp. wyomingensis [Beetle \& A. Young] S.L. Welsh; hereafter wyomingensis) and mountain big sagebrush (A. t. ssp. vaseyana [Rydb.] Beetle; hereafter vaseyana) - generally occupy different topographic positions (i.e., lower- and higher-elevation sites, respectively; Meinke et al. 2009) and vary widely in terms of resilience to environmental stress and resistance to invasion by exotic annual grasses, as well as in temperature and precipitation regimes (Wisdom and Chambers 2009, Chambers et al. 2017). In addition, soils occurring in both plant communities are considered well drained, but soils found in vaseyana sagebrush communities are typically deeper, finer textured, and higher in organic matter (Jensen 1990, Mahalovich and McArthur 2004, McArthur 2005, Davies et al. 2007). In contrast, coarser soils found in wyomingensis sagebrush communities drain more rapidly and experience higher rates of evaporation due to higher sand and lower organic matter content (Bauer 1974, Kuss 1986, Wang et al. 2016). Despite these documented differences, relatively little is known about how variation in soil properties influences recruitment opportunities of restoration species that are actively seeded in both communities to improve ecosystem health by remediating degraded herbaceous understory conditions (West 1988, Miller et al. 2011). Some species may be more or less suitable for a given community type; thus, inquiry into species performance will identify potential site-specific limitations on seeding success and inform future restoration activities.

The roles of soil texture and soil organic matter in determining plant community dynamics and restoration potential have gained recognition in the last few decades (Bronick and Lal 2005, Heneghan et al. 2008, Baer et al. 2010). Soil texture is a crucial soil property that directly influences moisture content, porosity, bulk density, organic matter stability, cation exchange capacity, and nutrient availability (Bauer 1974, Tuller and Or 2004, Saxton and Rawls 2006). Sandy soils have high porosity and low water-holding capacity (WHC), while clayey soils have higher bulk density, greater surface area, and higher WHC (Noy-Meir 1973, Lin et al. 1997). Soil organic matter (OM) content also strongly influences WHC of soils and water retention; namely, increasing OM generally increases WHC (Baumann and Bauer 1974, Naeth et al. 1991, Hudson 1994, Huntington 2006). Accordingly, differences in soil texture and OM content between wyomingensis and vaseyana soils may lead to considerable variation in WHC (i.e., Jensen 1989, 1990).

Seed germination and seedling emergence are recognized as major regulators of restoration success in semiarid ecosystems in the Intermountain West (James et al. 2013, Svejcar et al. 2014). However, little is known regarding how WHC influences germination and seedling emergence of commonly seeded species in this region. Although seeded species success can be improved by soil surface modifications to increase the number of favorable microsites for seed germination and emergence, as well as by seed enhancements to remedy restoration barriers (Mangold et al. 2007, Hardegree et al. 2016, Madsen et al. 2016), site-specific factors, such as soil properties, can have overriding effects on germination and emergence patterns of seeded species (Stevens 1983, Young et al. 1990, Brabec et al. 2015). Inherent site differences in WHC among sagebrush soils may dictate the amount of water freely available for seeds to imbibe and germinate (e.g., Evans and Etherington 1990) as well as the matric water potential (i.e., water stress) and retention when soils are exposed to evaporation, all of which directly influence potential germination and seedling emergence of seeds (Doescher et al. 1985, Wuest and Lutcher 2013). Thus, seeds in wyomingensis and vaseyana soils could experience vastly different soil water conditions, which may become more pronounced under lower soil moisture contents due to greater 
water retention and lower evaporation in finertextured vaseyana soil and more rapid evaporation in coarse-textured wyomingensis soil.

Native species seedling establishment patterns have been correlated with habitat conditions (i.e., elevation, temperature) in big sagebrush plant communities (Meyer and Monsen 1992, Kitchen and Monsen 1994, Hardegree and Van Vactor 1999), yet the influence of soil properties on species germination and seedling emergence patterns is poorly understood. Furthermore, controlled experiments have not previously been conducted to develop a mechanistic understanding of how the soil properties known to regulate WHC might influence seedling emergence patterns. To clarify these relationships, we evaluated the effects of vaseyana and wyomingensis soils on emergence patterns of 6 restoration species commonly seeded on degraded sagebrush plant communities in the Intermountain Region. A novel experimental design was developed to account for expected WHC differences between soils by regularly wetting soils to standardized soil water potentials (i.e., field capacity; -0.03 $\mathrm{MPa})$ and allowing differences in evaporation rates to create distinct wet-dry cycles over periods of emergence. We tested 3 hypotheses: (1) seedling emergence is higher in vaseyana soils due to greater WHC and water retention than in wyomingensis soils; (2) different seedling emergence patterns develop over time in vaseyana and wyomingensis soils; and (3) differences in seedling emergence patterns between vaseyana and wyomingensis soils become more pronounced under low SWC due to greater evaporation in wyomingensis soils. Assessing emergence patterns of these 2 soils will improve our understanding of species suitability for restoration sites and provide insights into site-related constraints on seeding success.

\section{Methods}

\section{Site Descriptions}

Soils from 2 different big sagebrush plant communities in northern Utah, dominated by either Wyoming (Artemisia tridentata ssp. wyomingensis) or mountain (Artemisia tridentata ssp. vaseyana) big sagebrush, were collected for use in this study. The Wyoming big sagebrush plant community was located near Park Valley in Box Elder County, Utah $\left(41^{\circ} 49^{\prime} 26.21^{\prime \prime} \mathrm{N}, 113^{\circ} 17^{\prime} 25.21^{\prime \prime} \mathrm{W}\right)$, at $1680 \mathrm{~m}$ elevation on a $3 \%$ south-facing slope. The parent material is derived from alluvium; soils are in the Kapod and Donnardo series and classified as loamy-skeletal, mixed, superactive, mesic Calcic Argixerolls and loamyskeletal, mixed, superactive, mesic Typic Argixerolls, respectively (Box Elder County, Western Part; http://websoilsurvey.nrcs.usda.gov/app/). The plant community was classified as Semidesert Gravelly Loam (Wyoming Big Sagebrush) North (R028AY215UT; Ecological Site Information System, https://esis.sc.egov.usda .gov). Vegetation resembled a Wyoming big sagebrush-dominated phase, with a number of less common species including rubber rabbitbrush (Ericameria nauseosa [Pall. ex Pursh] G.L. Nesom \& Baird), bottlebrush squirreltail (Elymus elymoides [Raf.] Swezey ssp. elymoides), and bluebunch wheatgrass (Pseudoroegneria spicata [Pursh] Á. Löve). Long-term (30-year; 1986-2016) mean annual precipitation and air temperature are $368.3 \mathrm{~mm}$ and $7.8^{\circ} \mathrm{C}$, respectively (Box Elder County, Western Part; http://websoilsurvey.nrcs.usda.gov/ app/).

The mountain big sagebrush plant community was located near Mantua in Box Elder County, Utah $\left(41^{\circ} 33^{\prime} 15.77^{\prime \prime} \mathrm{N}, 111^{\circ} 57^{\prime} 9.27^{\prime \prime} \mathrm{W}\right)$, at $1800 \mathrm{~m}$ elevation on a $10 \%$ north-facing slope. The parent material was quartzite alluvium derived from sandstone; soils are part of the Hendricks series and classified as finesilty, mixed, superactive, mesic Pachic Argixerolls (Box Elder County, Eastern Part; http:// websoilsurvey.nrcs.usda.gov/app/). Current vegetation was classified as Mountain Loam (Mountain Big Sagebrush) (R047XA430UT; Ecological Site Information System, https://esis .sc.egov.usda.gov); vegetation resembled a mountain big sagebrush-dominated phase with bluebunch wheatgrass (P. spicata) and a number of less common species including mountain snowberry (Symphoricarpos oreophilus A. Gray) and prairie junegrass (Koeleria macrantha [Ledeb.] Schult). Long-term (30-year; 1986-2016) mean annual precipitation and air temperature were $622.3 \mathrm{~mm}$ and $6.1{ }^{\circ} \mathrm{C}$, respectively (Box Elder County, Eastern Part; http://websoilsurvey.nrcs.usda.gov/app/).

\section{Soil Collection and Analysis}

Soil was excavated to a depth of $20 \mathrm{~cm}$ from the interspace areas between shrub plants 
within a single $10 \times 10$-m area at each plant community, excluding the top litter layer, until $100 \mathrm{~L}$ of soil was obtained. Soils were transported to a greenhouse, homogenized by mixing, and air-dried for 3 weeks before sieving through a $1-\mathrm{cm}$ wire mesh to remove large organic material and rock.

Air-dried subsamples from each soil $(n=5)$ were analyzed for cation exchange capacity (CEC), organic matter content (OM), WHC (determined by percent soil water content [SWC \%] at $-0.03 \mathrm{MPa},-1.5 \mathrm{MPa}$, and soil saturation), $\mathrm{pH}$, and percentages of sand, silt, and clay. CEC and OM were determined with flow injection analysis (Quick Chem 8500, Lachat Instruments, Loveland, CO) using the ammonium replacement method (Gavlak et al. 2005) and the dichromate oxidation method (Walkley and Black 1934), respectively. Percentage SWC values were measured with the pressure plate method (Gavlak et al. 2005) at $-0.03 \mathrm{MPa}$, and the samples were allowed to equilibrate for $24 \mathrm{~h}$. For permanent wilting point, the pressure plate was set at $-1.5 \mathrm{MPa}$ and allowed to equilibrate for $48 \mathrm{~h}$. SWC values are expressed gravimetrically (i.e., the weight of water as a fraction of the total soil wet weight; Bittelli 2011). Samples were also analyzed for $\mathrm{pH}$ and percent sand, silt, and clay using the slurry and hydrometer methods, respectively (Gee and Bauder 1986, Thomas 1996). For $\mathrm{pH}, 15 \mathrm{~g}$ of soil was mixed with $30 \mathrm{~mL}$ of deionized water, shaken at $100 \mathrm{rpm}$ for $30 \mathrm{~min}$, then measured with a $\mathrm{pH}$ meter (Orion $3 \mathrm{pH}$ meter; Thermo Scientific Beverly, MA). To quantify percent sand, silt, and clay, $50 \mathrm{~g}$ of soil was mixed with a $100-\mathrm{mL}$ sodium hexametaphosphate-water solution and $250 \mathrm{~mL}$ of deionized water and shaken at $150 \mathrm{rpm}$ for $1 \mathrm{~h}$. The resultant solution was placed into a 1-L cylinder, which was then filled with deionized water. A custom plunger was used to mix the slurry before its temperature $\left({ }^{\circ} \mathrm{C}\right)$ and density $(\mathrm{g} / \mathrm{L})$ were measured with a Bouyoucos hydrometer (14-331-5C; Thermo Scientific, Beverly, MA) after $30 \mathrm{~s}$ and again after $1440 \mathrm{~min}$. Soil variables were compared between soils using the unpaired (i.e., independent samples) 2-sample Student's $t$ test $(\alpha=0.05)$.

\section{Plant Species}

Six species commonly used in restoration projects in the Great Basin, Rocky Mountain, and Colorado Plateau ecoregions in the Intermountain West were selected for our study (UWRI; https://wri.utah.gov/wri; Lambert 2005, Wilder et al. 2018). These included the shrubs Wyoming and mountain big sagebrush, 2 forbs (alfalfa Medicago sativa [L.] and sanfoin Onobrychis viciifolia Scop.), and 2 perennial grasses (bluebunch wheatgrass Pseudoroegneria spicata and "Hycrest II" crested wheatgrass Agropyron cristatum [L.] Gaertn). Seeds for the study were obtained from Great Basin Research Center and Seed Warehouse, Ephraim, Utah (shrubs-wildland collected at Piute/Wayne/ Sevier counties in Utah in fall 2016) and Wheatland Seed, Brigham City, Utah (forbs and grasses-commercially produced in Utah 2015). Seeds were hand cleaned and selected for consistency in shape and size prior to experiments.

\section{Experiment 1: Emergence under Field Capacity}

To study the influence of sagebrush soils on seed emergence over time, 100 seeds of each species were sown in plastic containers $(11 \times$ $11 \times 4 \mathrm{~cm}[\mathrm{~L} \times \mathrm{W} \times \mathrm{H}])$ filled with $50 \mathrm{~g}$ of either vaseyana or wyomingensis soil (5 replicates $\times 2$ soils $\times 6$ species $=60$ ). This sowing density was chosen because it allowed seeds to be equally spaced $1 \mathrm{~cm}$ apart in a $10 \times 10$ grid and because it allowed for easy calculation of percent emergence as opposed to matching a seeding rate used in restoration. Following seeding recommendations of Jensen et al. (2001), we then covered seeds with either $1 \mathrm{~mm}$ of soil (sagebrush) or $3 \mathrm{~mm}$ of soil (all other species) and placed unsealed containers in a growth chamber with onboard environmental controls (model PGW132, IntellusUltra C8T, Percival, Perry, IA) for photosynthetically active radiation (PAR), air temperature, and relative humidity $(\mathrm{RH} \%)$. The chamber was set to a 12:12 h day:night regime, and temperature and $\mathrm{RH}$ values were chosen to mimic a springtime regime (e.g., 15 April to 15 May) for Tremonton, Utah, a site located geographically between the 2 plant communities where soils were obtained. Spring conditions were mimicked due to the fact that these species are typically sown with fall-dormant seeding to promote spring emergence when soil water is available and the risk of seedling mortality from freezing temperatures is low (Jensen et al. 2001). We obtained average 
TABLE 1. Mean ( \pm SE; $n=5)$ soil measures and statistical comparison (unpaired Student's $t$ test and $P$ value) of 2 big sagebrush plant community soils used in seed germination experiments (wyomingensis = Wyoming big sagebrush [Artemisia tridentata ssp. wyomingensis $]$ and vaseyana $=$ mountain big sagebrush $[$ A. $t$. ssp. vaseyana]).

\begin{tabular}{|c|c|c|c|c|}
\hline Soil measure & vaseyana soil & wyomingensis soil & $t$ & $P$ \\
\hline Organic matter $(\%)$ & $7.86 \pm 0.06$ & $3.78 \pm 0.13$ & 34.23 & $<0.0001$ \\
\hline SWC \% $(-0.03 \mathrm{MPa})$ & $34.58 \pm 0.49$ & $20.82 \pm 0.36$ & 16.63 & $<0.0001$ \\
\hline SWC \% (-1.5 MPa) & $15.34 \pm 0.16$ & $6.51 \pm 0.15$ & 52.85 & $<0.0001$ \\
\hline SWC \% (saturated soil) & $58.90 \pm 0.59$ & $29.43 \pm 0.35$ & 45.90 & $<0.0001$ \\
\hline Sand $(\%)$ & $15.61 \pm 0.85$ & $65.60 \pm 0.31$ & -57.11 & $<0.0001$ \\
\hline Silt $(\%)$ & $47.83 \pm 0.84$ & $23.34 \pm 0.29$ & 26.15 & $<0.0001$ \\
\hline Clay $(\%)$ & $36.52 \pm 0.43$ & $11.06 \pm 0.09$ & 64.93 & $<0.0001$ \\
\hline
\end{tabular}

hourly air temperature and RH data for Tremonton from the Utah Climate Center (https://climate.usurf.usu.edu/agweather.php) and calculated mean daytime (09:00-21:00) and nighttime (21:00-09:00) values for a 4-year period (2013-2016). Based on these calculations, we set the day: night temperature and RH to $14.6: 8.4{ }^{\circ} \mathrm{C}$ and $50.9 \%: 70.8 \%$, respectively. Daytime PAR was set to an uncharacteristically low PAR value of $100 \mu \mathrm{mol}$. $\mathrm{m}^{-2} \mathrm{~s}^{-1}$ to prevent high rates of evaporation within the small containers over a 24 -h period. To begin the experiment, SWC of each container was adjusted gravimetrically according to values equating to field capacity (i.e., -0.03 $\mathrm{MPa}$ ) for each soil (i.e., $35 \%$ and $21 \%$ for vaseyana and wyomingensis soils, respectively; Table 1). Thereafter, we recorded daily low SWC (i.e., after a 24 -h period) for each container and readjusted SWC to field capacity by applying water as a fine mist to the soil surface using a spray bottle. In addition, we recorded emergence (based on the appearance of a coleoptile extending $2 \mathrm{~mm}$ above the soil surface) for each container for $26 \mathrm{~d}$, a period after which no additional emergence was detected for 3 consecutive days (Supplementary Material 1). Emergence data were assessed for normality and homogeneity of variance, then analyzed for final seedling emergence with mixed-model ANOVA (Hypothesis 1) and repeated measures MANOVA (Hypotheses 2). Both models used a randomized complete block design and were analyzed as a factorial experiment with species and soils as fixed factors and replication as a random effect $(\alpha=$ 0.05). Repeated measures analyses tested the null hypothesis that patterns (i.e., profiles) of emergence are the same between the soils. Final emergence values revealed that emergence was generally higher in vaseyana soil compared to wyomingensis soil. Consequently, we used mean seedling emergence percentages in vaseyana soil as an in situ estimate of maximum species emergence in order to modify sowing densities in Experiment 2.

\section{Experiment 2: Emergence under Variable Water Levels}

To study the interactive influence of soil water content and sagebrush soil on seedling emergence patterns, we followed the same procedures of Experiment 1, but to minimize intraspecific competition within the small containers, seeds were sown at a lower density and emergence was tracked over a 29-d period, a period after which no additional emergence was detected for 3 additional days (Supplementary Material 1). Using maximum emergence estimates obtained from Experiment 1 , sowing density was calculated for each species in order to potentially yield 30 seedlings per container. Total soil weight within containers was increased to $200 \mathrm{~g}$; increased soil volume allowed us to create distinct watering levels that could be maintained feasibly over a 24 -h period. A total of 120 containers were prepared for the experiment ( 2 soils $\times 2$ water levels $\times 6$ species $\times 5$ replicates).

Distinct water levels were created by adjusting daily SWC to either field capacity (high treatment) or to the midpoint between field capacity and the permanent wilting point (low treatment). Midpoint SWC levels for vaseyana and wyomingensis soils were $25.0 \%$ and $13.7 \%$, respectively. Thus, unlike Experiment 1 , adjustments were not made each day, but only when the SWC of at least one container from a species-water level combination reached permanent wilting point due to evaporation. Gravimetric SWC and seedling emergence were recorded daily even if water adjustments were not necessary. Seedling emergence data were assessed for normality 


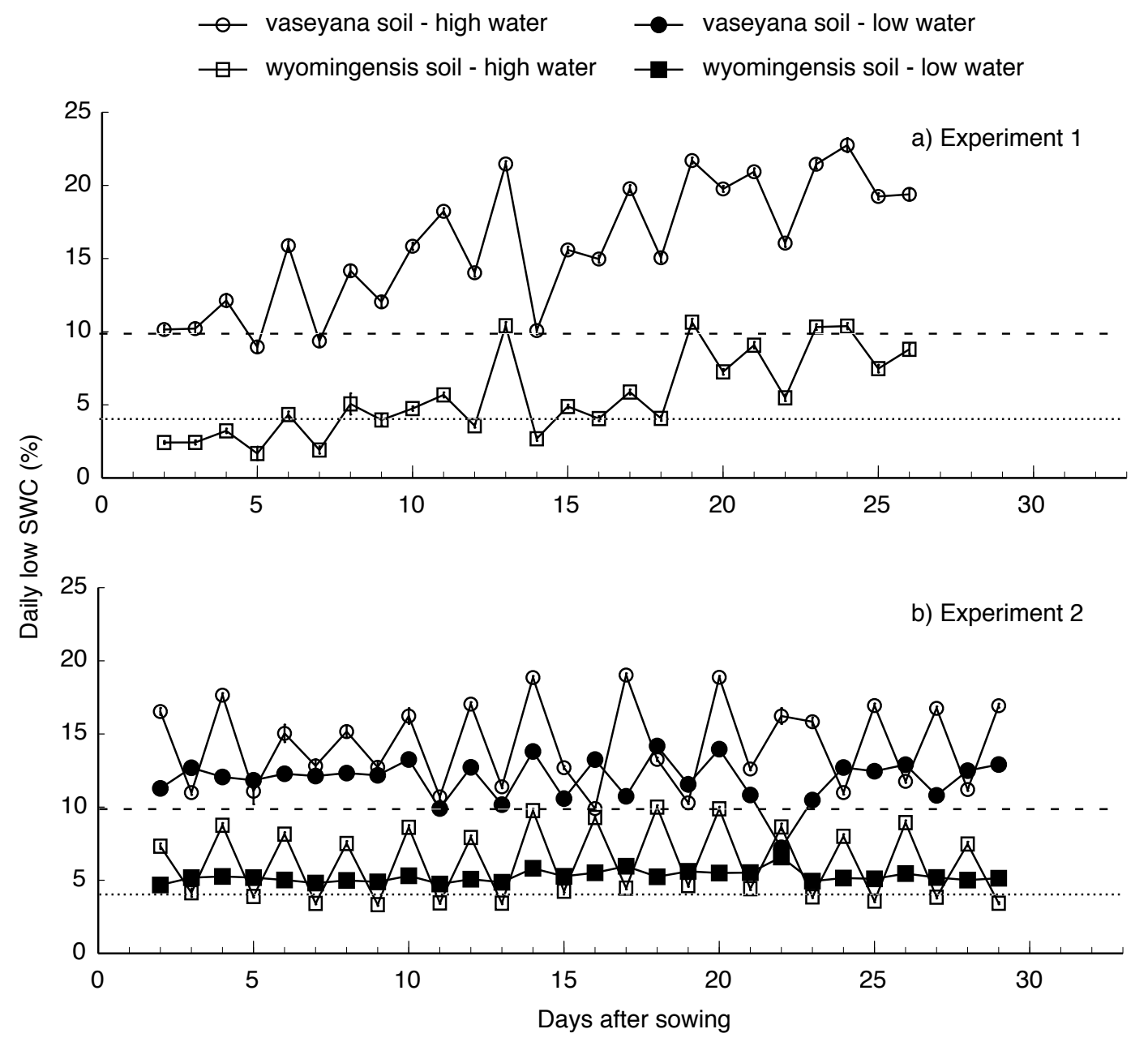

Fig. 1. Analysis of daily-low percent soil water content (SWC) in Experiments 1 and 2. Dashed and dotted lines indicate SWC values at the permanent wilting point (i.e., $-1.5 \mathrm{MPa}$ ) for vaseyana (mountain big sagebrush, Artemisia tridentata ssp. vaseyana) and wyomingensis (Wyoming big sagebrush, A. $t$. ssp. wyomingensis) soils, respectively. Experiment 1 had one water level (i.e., high water content) and Experiment 2 incorporated 2 water levels (i.e., high and low water content).

and homogeneity of variance and analyzed as described in Experiment 1, but with the additional factor of water level in order to test Hypothesis 3. Statistical analyses in both experiments were conducted in JMP ver. 13 (SAS Institute Inc., Cary, NC).

\section{RESUlTS}

Soil Properties and Water Content

Differences between vaseyana and wyomingensis soils were highly significant (Table 1, Supplementary Material 2). Organic matter as well as the silt and clay content of vaseyana soil were typically twofold higher than those of wyomingensis soil (Table 1). Sand content of wyomingensis soil was roughly fourfold higher than of vaseyana soil. Consequently, vaseyana soils required nearly twice the amount of water to attain the same soil water potential (i.e., field capacity; $-0.03 \mathrm{MPa}$ ), and thus, WHC (i.e., SWC at predetermined water potential) of vaseyana soils remained much higher relative to wyomingensis soils for both experiments (Fig. 1). Even when distinct soil water levels were applied in Experiment 2 , the low water level of vaseyana soil maintained higher daily-low percent SWC than 

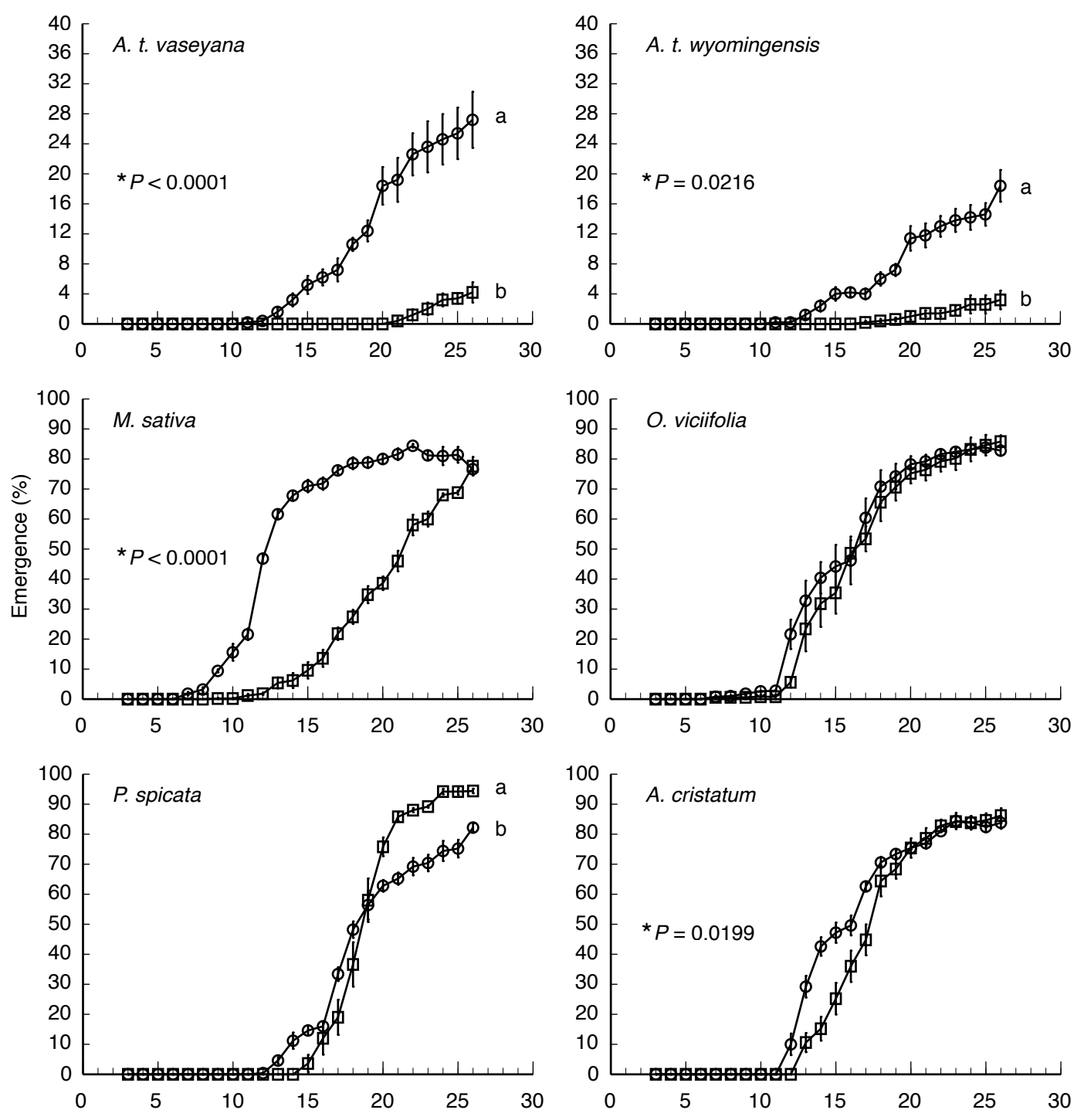

Days after sowing

Fig. 2. Daily percent emergence (mean $\pm \mathrm{SE}$ ) of 6 species (Artemisia tridentata vaseyana, A. $t$. wyomingensis, Medicago sativa, Onobrychis viciifolia, Pseudoroegneria spicata, and Artemisia cristatum) in Experiment 1. Emergence was assessed daily for $26 \mathrm{~d}$ in vaseyana (mountain big sagebrush, Artemisia tridentata ssp. vaseyana) and wyomingensis (Wyoming big sagebrush, A. $t$. ssp. wyomingensis) soils. $P$ values indicate significant differences between soils and lowercase letters indicate significant differences between final emergence values. Note that different $y$-axis scales are used.

both water levels of the wyomingensis soil. Vaseyana soil also retained water longer than wyomingensis soil based on the fact that the number of watering events (i.e., mean \pm SE, pooled across species) was approximately dou- ble for wyomingensis compared to vaseyana soil in both the high $(9.0 \pm 0.0$ vs. $14.1 \pm 0.1$; $t=36.0, \mathrm{df}=6, P<0.0001)$ and low water level treatment $(14.0 \pm 0.3$ vs. $25.0 \pm 0.6$; $t=$ $15.2, \mathrm{df}=6, P<0.0001)$. 
TABLE 2. Results of MANOVA showing degrees of freedom (df), $F$ statistics, and $P$ values for the effects of sagebrush community soil (wyomingensis $=$ Wyoming big sagebrush [Artemisia tridentata ssp. wyomingensis] and vaseyana $=$ mountain big sagebrush $[A . t$. ssp. vaseyana $]$ ) on germination of 6 species in Experiment 1.

\begin{tabular}{lcrc}
\hline Effect & df & \multicolumn{1}{c}{$F$} & \multicolumn{1}{c}{$P$} \\
\hline Soil & 1,48 & 83.68 & $<0.0001$ \\
Species & 5,48 & 290.52 & $<0.0001$ \\
Soil * Species & 5,48 & 26.01 & $<0.0001$ \\
\hline
\end{tabular}

\section{Seedling Emergence}

In Experiment 1, seedling emergence was significantly higher in vaseyana soil than in wyomingensis soil, and species exhibited vastly different patterns in the 2 soils (Fig. 2, Table 2 ). Final emergence percentages were much higher in vaseyana soil for both sagebrush subspecies compared to the wyomingensis soil, but not for the other 4 restoration species. Emergence was also notably higher for $M$. sativa and A. cristatum in vaseyana soil, but only during the midpoint of the experiment. In addition, emergence patterns of $O$. viciifolia and $P$. spicata were not significantly affected by the different sagebrush soils, although patterns for $P$. spicata in the wyomingensis soil showed a marked increase over vaseyana soil between days 20 and 26 of the experiment. Consequently, although emergence patterns were significantly different between vaseyana and wyomingensis soils (Table 2), final percentage values (mean $\pm \mathrm{SE}$, pooled for species) differed by $<4 \%$ (i.e., 61.8 \pm 5.2 vs. $58.6 \pm 7.3$, respectively).

Although water was added less frequently in Experiment 2 relative to Experiment 1, the patterns of species emergence and how they were influenced by soils were similar. Emergence was generally rapid and high for the combination of high water and vaseyana soil for many species, yet a number of exceptions were observed (Fig. 3). For example, unlike the other species, final emergence of $P$. spicata in wyomingensis soil exceeded that in vaseyana soil regardless of soil water level. In addition, $O$. viciifolia showed greater emergence in wyomingensis than in vaseyana soil under low water. Water levels also modulated emergence patterns differently among species (Fig. 3, Table 3). Significant differences in seedling emergence patterns between soils were not found for either sagebrush subspecies or O. viciifolia under the high water level. In contrast, emergence patterns for M. sativa, P. spicata, and A. cristatum were different between soils, regardless of water level. However, differences between soils were more pronounced under low water only for O. viciifolia and P. spicata. Although pooled-species emergence patterns were significantly different between vaseyana and wyomingensis soils (Table 3), final percentage values (mean $\pm \mathrm{SE}$, pooled for species) were similar under high water $(56.0 \pm 5.0$ vs. $55.5 \pm 5.9)$, but quite different under low water $(32.8 \pm 3.6$ vs. 50.2 \pm 5.2 ).

\section{Discussion}

Our results support the assumption that variations in soil texture and $\mathrm{OM}$ between vaseyana and wyomingensis soils translate into fundamental differences in soil waterholding capacity (i.e., Bauer 1974, Lin et al. 1997) and that these differences suggest a number of important considerations relevant to seed emergence patterns. First, finer-textured vaseyana soils had greater WHC (roughly twofold higher SWC) than coarser-textured wyomingensis soils. Thus, differences in evaporation between soils created fluctuating SWC conditions and highly variable seedling emergence patterns for a broad range of restoration species. For example, differences in SWC between soils exposed germinating seeds in vaseyana soils to fewer watering events and less frequent wet-dry cycles compared to wyomingensis soils. In addition, this signature difference in SWC between soils became more pronounced on emergence in the low water level treatment for 2 of the study species. Second, because soils and species strongly interacted, we rejected our 3 hypotheses because all species did not experience higher emergence rates in vaseyana soil, all species did not experience different emergence patterns in the 2 soils, and differences in emergence patterns between soils were not consistently more pronounced under the low water treatment. Collectively, the rejection of these hypotheses clearly illustrates that there is still much to be learned about the influence of inherent soil properties on seedling emergence of important restoration species.

Differences in soil texture and OM content between wyomingensis and vaseyana soils directly influenced evaporative water loss 

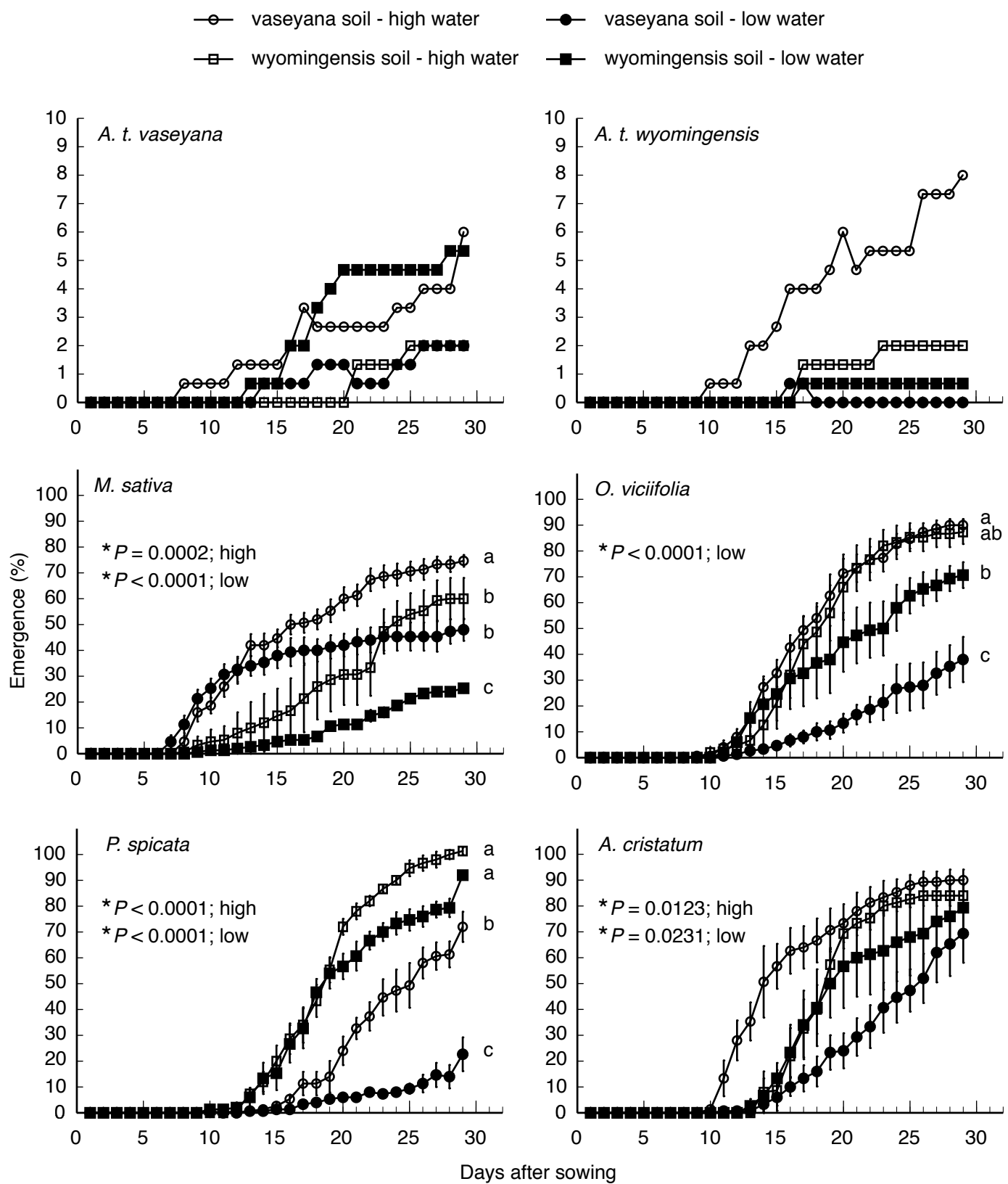

Fig. 3. Daily percent emergence (mean $\pm \mathrm{SE}$ ) of 6 species (Artemisia tridentata vaseyana, A. $t$. wyomingensis, Medicago sativa, Onobrychis viciifolia, Pseudoroegneria spicata, and Artemisia cristatum) in Experiment 2. Emergence was assessed daily for $29 \mathrm{~d}$ in vaseyana (mountain big sagebrush, Artemisia tridentata ssp. vaseyana) and wyomingensis (Wyoming big sagebrush, A. $t$. ssp. wyomingensis) soils. Within water content levels, $P$ values indicate significant differences between soils, and lowercase letters indicate significant differences between final emergence values. Note that for easier viewing, error bars are not shown for sagebrush emergence values. Also note that different $y$-axis scales are used.

(e.g., Bauer 1974, Saxton and Rawls 2006) and exposed germinating seeds to different wetdry cycles. While rapid evaporation of moisture is known to limit germination of semiarid plant species (e.g., Frasier et al. 1987), alternating wet-dry cycles have been found to accelerate germination and seedling emergence (Zhu et al. 2014); still, responses can vary 
TABLE 3. Results of MANOVA showing degrees of freedom (df), $F$ statistics, and $P$ values for the effects of sagebrush community soil (wyomingensis = Wyoming big sagebrush [Artemisia tridentata ssp. wyomingensis] and vaseyana $=$ mountain big sagebrush $[A . t$. ssp. vaseyana $]$ ) and soil water content levels on germination of 6 species in Experiment 2.

\begin{tabular}{lcrr}
\hline Effect & df & \multicolumn{1}{c}{$F$} & \multicolumn{1}{c}{$P$} \\
\hline Soil & 1,92 & 2.07 & 0.1536 \\
Species & 5,92 & 87.19 & $<0.0001$ \\
Water & 1,92 & 63.77 & $<0.0001$ \\
Soil*Species & 5,92 & 22.59 & $<0.0001$ \\
Soil*Water & 1,92 & 12.56 & $<0.0001$ \\
Water*Species & 5,92 & 6.42 & $<0.0001$ \\
Soil*Species*Water & 5,92 & 3.10 & 0.0124 \\
\hline
\end{tabular}

widely among species native to the Intermountain Region (Bleak and Keller 1972, Kastner et al. 1981). Furthermore, the influence of alternating wet-dry cycles on germination rates (e.g., Doescher et al. 1985, Evers and Parsons 2003) depends on the interval length between rewetting events (Fay and Schultz 2009, Gao et al. 2015). In both of our experiments, interval lengths were greater for vaseyana soil, while rewetting occurred more frequently in wyomingensis soils. In addition, seeds in Experiment 2 were exposed to 6 and 11 more wet-dry cycles in the wyomingensis high and low water treatments, respectively, compared to the vaseyana soils. These differences in wet-dry cycles provide an important clarification when interpreting emergence patterns overall (i.e., pooled-species responses) as well as for individual species.

Considerable variation in final emergence values and emergence patterns among species necessitated rejecting Hypotheses 1 and 2. Instead, we found that the greater WHC of vaseyana soil did not consistently lead to higher emergence or distinct emergence patterns compared to the coarser wyomingensis soil. In fact, emergence differences between soils were evident for only 4 of the 6 species in Experiment 1 (Fig. 2), and of these, only the sagebrush subspecies clearly illustrated greater final emergence values in vaseyana soil. Considering both experiments together, only $M$. sativa and A. cristatum responded according to Hypothesis 2. We speculate that the greater emergence in vaseyana soil than in wyomingensis soil for both sagebrush subspecies in Experiment 1, where seeds were planted more shallowly than in Experiment 2, exposed seeds to more rapid evaporation between watering intervals in wyomingensis soil than in vaseyana soil (e.g., Gill and Jalota 1996), which increased the chances of dry soils desiccating seeds between watering intervals. Sagebrush seeds are very small compared to the seeds of other species in our study, and require shallow seeding depths (Meyer 1994, Walck et al. 2008, Daws et al. 2008). Thus, rapid emergence under the higher SWC and less fluctuating water conditions of vaseyana soil may be a mechanism to reduce the risk of droughtinduced mortality of these species. On the other hand, consistently more rapid emergence of the broadly adapted $M$. sativa and A. cristatum in vaseyana soil suggests that both species benefited from the buffered (i.e., less extreme) changes in daily SWC provided by finer-textured vaseyana soils. Less wet-dry cycling in the vaseyana soil over the course of our experiments likely improved $M$. sativa emergence by increasing the rate of imbibition, a process known to strongly control germination speed and consistency in this legume (Hegarty 1977, Chon et al. 2004, Yacoubi et al. 2011). Greater emergence of A. cristatum in vaseyana soil also appears to be related to higher soil water retention in finer soils. This aggressive forage grass has been shown to be most productive and to maintain dominance on silty loam soils compared to sandy loam soils in the Intermountain Region (Shown et al. 1969, Williams et al. 2017). In addition, previous research has illustrated that supplementing field soils with sand to reduce waterholding capacity resulted in significant reductions in crested wheatgrass germination and seedling emergence (Mangold and Sheley 2007).

Water content of surface-soil horizons can fluctuate greatly from day to day in sagebrush ecosystems (Obrist et al. 2004, Ivans et al. 2006 ) and can vary by vegetation type (Castelli et al. 2000, Ducas et al. 2011), particularly during spring conditions that coincide with seed germination and seedling emergence of seeded species (Schlaepfer et al. 2015). Soil water depletion can be rapid if soils are not recharged by precipitation or through hydraulic redistribution. Such diel fluctuation in soil surface water conditions can be extreme, and it reflects (1) daytime depletion due to evaporation and transpiration and (2) nocturnal recharge by hydraulic redistribution and flow of vapor and liquid along temperature and 
pressure potential gradients (Caldwell et al. 1998, Schelde et al. 1998). These environmental gradients make it difficult to measure soil water conditions at the soil surface, yet from modeling, we know that fluctuations in water and temperature strongly regulate seed germination patterns (Flerchinger and Hardegree 2004, Hardegree et al. 2013). When soils become dry and are not recharged, available soil water conditions are not suitable for seeded species germination and may lead to desiccation and mortality of emerged seedlings (Evans et al. 1970, Abbott and Roundy 2003, James and Svejcar 2010, James et al. 2011). Although pooled-species emergence patterns suggested that differences between soils became more pronounced under low water in Experiment 2, Hypothesis 3 must be rejected because not all individual species responded this way. In fact, O. viciifolia and P. spicata were the only species with more pronounced differences between soils under low water; however, surprisingly, both species showed higher emergence rates in wyomingensis soil, rather than in vaseyana soil. A mechanism for these unexpected results is difficult to speculate on, but it is possible that longer interval lengths spent at suboptimal water conditions in vaseyana soil reduced emergence relative to coarser wyomingensis soil, which was recharged more frequently due to higher evaporation rates. Greater emergence of $P$. spicata in wyomingensis soil than vaseyana soil regardless of water level also agrees with a previous report that showed twofold greater germination in sandy compared to clayey soil (Madsen et al. 2012). Further research that expressly varies the temporal dynamics of wet-dry cycles is needed to characterize germination and emergence patterns in soils of different textures and for different species.

\section{Implications}

Our results, which show variable species emergence patterns for vaseyana and wyomingensis soils, provide a greater understanding of the mechanisms influencing species suitability for restoration sites and offer new insights into site-related constraints on seeding success. In particular, our observations indicate that a given seed mix will behave differently on wyomingensis versus vaseyana soils. Emergence was generally greater in vaseyana soil and within the high water treatment, yet the low water treatment did not seem to prevent any of the species from emerging. In a few cases, the magnitude of differences in emergence between the 2 soils was greater under low water treatments, which was likely caused by alternating wet-dry cycles promoting water imbibition and increasing germination. This information has relevance to those interested in how drought and climate could change seedling emergence in restoration sites (Wilder et al. 2018). In addition, the variation between species in response to water and soil factors demonstrates that restoration seed mixes could be potentially improved by matching species to specific soil types. To expedite this endeavor, further research is needed to characterize the role of soil texture on seedling emergence of a broader range of important restoration species, while accounting for its influence on the temporal dynamics of alternating wet-dry cycles. Ultimately, this approach could assist in determining the suitability of sites for proposed restoration seedings, as well as in selecting the most appropriate species to plant.

\section{Supplementary Material}

Two online-only supplementary files accompany this article (scholarsarchive.byu.edu/ wnan/vol79/iss2/9).

Supplementary Material 1. Actual numbers of seeds sown and emergents for 6 species grown in different sagebrush community soils.

Supplementary Material 2. Mean cation exchange capacity and soil $\mathrm{pH}$ compared statistically between 2 big sagebrush plant community soils used in seed germination experiments.

\section{ACKNOWLEDGMENTS}

We thank Justin Williams and Ramsey Buffham of the USDA, Agricultural Research Service, Forage and Range Research Lab., Logan, Utah, for maintaining growth chambers and for help with collecting soils. We also thank Mitch Westmoreland, Juliann Otteson, and Tiffany Stewart for assisting with seedling counts. The Great Basin Research Center, Utah Division of Wildlife Resources in Ephraim, Utah, provided sagebrush seed. This research was funded by Great Basin Native Plant Project USDA-FS Award 15-JV- 
11221632-197 and Utah Agricultural Experiment Station projects UTA01071, UTA01222, and UTA01296. This research was supported by the Utah Agricultural Experiment Station, Utah State University, and approved as journal paper number 9046.

\section{Literature Cited}

Aввотt, L.B., AND B.A. Roundy. 2003. Available water influences field germination and recruitment of seeded grasses. Journal of Range Management 56: 56-84.

Baer, S.G., C.K. Meyer, E.M. BaCh, R.P. Klopf, and J. SIX. 2010. Contrasting ecosystem recovery on two soil textures: implications for carbon mitigation and grassland conservation. Ecosphere 1:art5.

BAUER, A. 1974. Influence of soil organic matter on bulk density and available water capacity of soils. Farm Research 31:44-52.

Baumann, G.E., AND A. Bauer. 1974. The performance of foundations on various soils stabilized by the vibrocompaction method. Canadian Geotechnical Journal 11:509-530.

Bittelli, M. 2011. Measuring soil water content: a review. HortTechnology 21:293-300.

Bleak, A.T., and W. Keller. 1972. Germination and emergence of selected forage species following preplanting seed treatment. Crop Science 12:9-13.

Brabec, M.M., M.J. Germino, D.J. Shinneman, D.S. PilLIOD, S.K. MCIlroy, and R.S. Arkle. 2015. Challenges of establishing big sagebrush (Artemisia tridentata) in rangeland restoration: effects of herbicide, mowing, whole-community seeding, and sagebrush seed sources. Rangeland Ecology and Management 68:432-435.

BRonick, C.J., AND R. LAL. 2005. Soil structure and management: a review. Geoderma 124:3-22.

Caldwell, M.M., T.E. Dawson, and J.H. Richards. 1998. Hydraulic lift consequences of water efflux from the roots of plants. Oecologia 113:151-161.

Castelli, R.M., R.J. Chambers, and R.J. Tausch. 2000. Soil-plant relations along a soil-water gradient in Great Basin riparian meadows. Wetlands 20:251-266.

Chambers, J.C., J.D. Maestas, D.A. Pyke, C.S. Boyd, M. Pellant, and A. Wuenschel. 2017. Using resilience and resistance concepts to manage persistent threats to sagebrush ecosystems and Greater Sage-Grouse. Rangeland Ecology and Management 70:149-164.

Chaney, L., B.A. Richardson, and M.J. Germino. 2017. Climate drives adaptive genetic responses associated with survival in big sagebrush (Artemisia tridentata). Evolutionary Applications 10:313-322.

Chon, S., C.J. Nelson, AND J.H. CoutTs. 2004. Osmotic and autoxic effects of leaf extracts on germination and seedling growth of alfalfa. Agronomy Journal 96:1673-1679.

Davies, K.W., J.D. Bates, AND R.F. Miller. 2006. Vegetation characteristics across part of the Wyoming big sagebrush alliance. Rangeland Ecology and Management 59:567-575.

Davies, K.W., J.D. Bates, and R.F. Miller. 2007. Environmental and vegetation relationships of the Artemisia tridentata spp. wyomingensis alliance. Journal of Arid Environments 70:478-494.
Daws, M.I., L.M. Crabtree, J.W. Dalling, C.E. Mullins, AND D.F. BursLem. 2008. Germination responses to water potential in neotropical pioneers suggest largeseeded species take more risks. Annals of Botany 102:945-951.

Doescher, P., R. Miller, and A. Windard. 1985. Effects of moisture and temperature on germination of Idaho fescue. Journal of Range Management 38:317-320.

Ducas, L.P., S.B. Jones, A.J. Leffler, and R.J. Ryel. 2011. Associations of near-surface soil moisture and annual plant community dynamics. Natural Resources and Environmental Issues 17:75-82.

Evans, C.E., And J.R. Etherington. 1990. The effect of soil water potential on seed germination of some British plants. New Phytologist 115:539-548.

Evans, R.A., H.R. Holbo, R.E. Eckert, and J.A. Young. 1970. Functional environment of downy brome communities in relation to weed control and revegetation. Weed Science 18:154-162.

Evers, G.W., AND M.J. Parsons. 2003. Soil type and moisture level influence on Alamo switchgrass emergence and seedling growth. Crop Science 43: 288-294.

FAY, P.A., AND M.J. Schultz. 2009. Germination, survival, and growth of grass and forb seedlings: effects of soil moisture variability. Acta Oecologica 35:679-684.

Flerchinger, G.N., And S.P. Hardegree. 2004. Modelling near-surface soil temperature and moisture for germination response predictions of post-wildfire seedbeds. Journal of Arid Environments 59:369-385.

Frasier, G.W., J.R. Cox, and D.A. Woolhiser. 1987. Wet-dry cycle effects on warm-season grass seedling establishment. Journal of Range Management 40: $2-6$.

GaO, R., X. Yang, G. Liu, Z. Huang, and J.L. Walck. 2015. Effects of rainfall pattern on the growth and fecundity of a dominant dune annual in a semi-arid ecosystem. Plant and Soil 389:335-347.

Gavlak, R.G., D.A. Horneck, and R.O. Miller. 2005. Soil, plant and water reference methods for the Western Region. 3rd edition. Western Region Environmental Program 125, University of Alaska, Fairbanks, AK. 206 pp.

GeE, G.W., AND J.W. BAuder. 1986. Particle-size analysis. Pages 383-411 in A. Klute, editor, Methods of soil analysis. Part 1. Physical and mineralogical methods. Soil Science Society of America, Madison, WI.

GiLL, B.S., AND S.K. JALOTA. 1996. Evaporation from soil in relation to residue rate, mixing depth, soil texture and evaporativity. Soil Technology 8:293-301.

Hardegree, S.P., T.A. Jones, B.A. Roundy, N.L. Shaw, AND T.A. Monaco. 2016. Assessment of range planting as a conservation practice. Rangeland Ecology and Management 69:237-247.

Hardegree, S.P., C.A. Moffet, G.N. Flerchinger, J. Cho, B.A. Roundy, T.A. Jones, J.J. James, P.E. Clark, and F.B. Pierson. 2013. Hydrothermal assessment of temporal variability in seedbed microclimate. Rangeland Ecology and Management 66: 127-135.

Hardegree, S.P., and S.S. Van Vactor. 1999. Predicting germination response of four cool-season range grasses to field-variable temperature regimes. Environmental and Experimental Botany 41:209-217.

Hegarty, T.W. 1977. Seed activation and seed germination under moisture stress. New Phytologist 78: 349-359. 
Heneghan, L., S.P. Miller, S. Baer, M.A. Callaham, J. Montgomery, M. Pavao-Zuckerman, C.C. Rhoades, AND S. RiCHARDSON. 2008. Integrating soil ecological knowledge into restoration management. Restoration Ecology 16:608-617.

Hudson, B.D. 1994. Soil organic matter and available water capacity. Journal of Soil and Water Conservation 49:189-194.

Huntington, T.G. 2006. Available water capacity and soil organic matter. Pages 139-143 in R. Lal, editor, Encyclopedia of soil science. Taylor and Francis, New York, NY.

Ivans, S., L. Hipps, A.J. Leffler, And C.Y. Ivans. 2006. Response of water vapor and $\mathrm{CO}_{2}$ fluxes in semiarid lands to seasonal and intermittent precipitation pulses. Journal of Hydrometeorology 7:995-1010.

James, J.J., R.L. Sheley, T. Erickson, K.S. Rollins, M.H. TAYlOR, AND K.W. DiXon. 2013. A systems approach to restoring degraded drylands. Journal of Applied Ecology 50:730-739.

JAMES, J.J., AND T. SvejCAR. 2010. Limitations to postfire seedling establishment: the role of seeding technology, water availability, and invasive plant abundance. Rangeland Ecology and Management 63:491-495.

James, J.J., T.J. Svejcar, and M.J. RinelLa. 2011. Demographic processes limiting seedling recruitment in arid grassland restoration. Journal of Applied Ecology 48:961-969.

Jensen, K.B., R.L. Reed, and R.E. Whitesides. 2001. Intermountain planting guide. AG 510. Utah State University Extension, Logan, UT.

JEnsen, M.E. 1989. Soil climate and plant community relationships on some rangelands of northeastern Nevada. Journal of Range Management 42:275-280.

JENSEN, M.E. 1990. Interpretation of environmental gradients which influence sagebrush community distribution in northeastern Nevada. Journal of Range Management 43:161-167.

Kastner, W.W., C.J. Goebel, and J.D. Maguire. 1981. Effects of a wet-dry seed treatment on the germination and root elongation of "Whitmar" beardless wheatgrass under various water potentials. Journal of Range Management 34:305-307.

Kitchen, S.G., And S.B. Monsen. 1994. Germination rate and emergence success in bluebunch wheatgrass. Journal of Range Management 47:145-150.

Kuss, F.R. 1986. A review of major factors influencing plant responses to recreation impacts. Environmental Management 10:637-650.

LAMberT, S.M. 2005. Seeding considerations in restoring big sagebrush habitat. Pages 75-80 in N.L. Shaw, M. Pellant, and S.B. Monsen, editors, Sage-grouse habitat restoration symposium proceedings. RMRSP-38, U.S. Department of Agriculture, Forest Service, Rocky Mountain Research Station, Fort Collins, CO.

Lin, H.S., K.J. McInnes, L.P. Wilding, and C.T. HallMARK. 1997. Low tension water flow in structured soils. Canadian Journal of Soil Science 77:649-654.

Madsen, M.D., K.W. Davies, C.S. Boyd, J.D. Kerby, And T.J. SvEJCAR. 2016. Emerging seed enhancement technologies for overcoming barriers to restoration. Restoration Ecology 24:S77-S84.

Madsen, M.D., K.W. Davies, C.J. Williams, and T.J. SvejCAR. 2012. Agglomerating seeds to enhance native seedling emergence and growth. Journal of Applied Ecology 49:431-438.
Mahalovich, M.F., and E.D. McArThur. 2004. Sagebrush (Artemisia spp.): seed and plant transfer guidelines. Native Plants Journal 5:141-148.

Mangold, J.M., J.J. James, AND R.L. Sheley. 2007. Presence of soil surface depressions increases water uptake by native grass seeds. Ecological Restoration 25:278-279.

Mangold, J.M., AND R.L. Sheley. 2007. Effects of soil texture, watering frequency, and hydrogel on the emergence and survival of coated and uncoated crested wheatgrass seeds. Ecological Restoration 25: 6-11.

McArThur, E.D. 2005. Sagebrush, common and uncommon, palatable and unpalatable Rangelands 27 : $47-51$.

Meinke, C.W., S.T. Knick, AND D.A. Pyke. 2009. A spatial model to prioritize sagebrush landscapes in the Intermountain West (U.S.A.) for restoration. Restoration Ecology 17:652-659.

MEYER, S.E. 1994. Germination and establishment ecology of big sagebrush: implications for community restoration. Pages 244-251 in S.B. Monsen and S.G. Kitchen, editors, Proceedings: ecology and management of annual rangelands. General Technical Report INT-313. U.S. Department of Agriculture, Forest Service, Intermountain Research Station, Ogden, UT.

Meyer, S.E., And S.B. Monsen. 1992. Big sagebrush germination patterns: subspecies and population differences. Journal of Range Management 45:87-93.

Miller, R.F., S.T. Knick, D.A. Pyke, C.W. Meinke, S.E. Hanser, M.J. Wisdom, AND A.L. Hild. 2011. Characteristics of sagebrush habitats and limitations to long-term conservation. Pages 144-184 in S.T. Knick and J.W. Connelly, editors, Greater Sage-Grouse: ecology and conservation of a landscape species and its habitats. Studies in Avian Biology, Volume 38. University of California Press, Berkeley, CA.

Naeth, M.A., A.W. Bailey, D.J. Pluth, D.S. Chanasyk, AND R.T. HARDIN. 1991. Grazing impacts on litter and soil organic-matter in mixed prairie and fescue grassland ecosystems of Alberta. Journal of Range Management 44:7-12.

Noy-Meir, I. 1973. Desert ecosystems: environment and producers. Annual Review of Ecology and Systematics 4:25-51.

Obrist, D., D. Yakir, and J.A. ARnOne. 2004. Temporal and spatial patterns of soil water following wildfireinduced changes in plant communities in the Great Basin in Nevada, USA. Plant and Soil 262:1-12.

Saxton, K.E., AND W.J. Rawls. 2006. Soil water characteristic estimates by texture and organic matter for hydrologic solutions. Soil Science Society of America Journal 70:1569-1578.

Schelde, K., A. Thomsen, T. Heidmann, P. Schjønning, AND P.E. JAnsson. 1998. Diurnal fluctuations of water and heat flows in a bare soil. Water Resources Research 34:2919-2929.

Schlaepfer, D.R., K.A. Taylor, V.E. Pennington, K.N. Nelson, T.E. Martyn, C.M. Rottler, W.K. LauenROTH, AND J.B. BRADFORD. 2015. Simulated big sagebrush regeneration supports predicted changes at the trailing and leading edges of distribution shifts. Ecosphere 6:art3.

Shown, L.M., R.F. Miller, and F.A. Branson. 1969. Sagebrush conversion to grassland as affected by precipitation, soil, and cultural practices. Journal of Range Management 22:303-311. 
ShultZ, L.M. 2009. Monograph of Artemisia subgenus Tridentatae (Asteraceae-Anthemideae). Systematic Botany Monographs 89:1-131.

Stevens, R. 1983. Species adapted for seeding mountain brush, big black and low sagebrush, and pinyonjuniper communities. Pages 78-82 in S.B. Monsen and N. Shaw, editors, Proceedings: managing Intermountain rangelands-improvement of range and wildlife habitats. U.S. Department of Agriculture, Forest Service, Intermountain Forest and Range Experiment Station, Ogden, UT.

Svejcar, T., J. James, S. Hardegree, and R. Sheley. 2014. Incorporating plant mortality and recruitment into rangeland management and assessment. Rangeland Ecology and Management 67:603-613.

Thomas, G.W. 1996. Soil pH and soil acidity. Pages 475490 in D.L. Sparks, A.L. Page, P.A. Helmke, R.H. Loeppert, P.N. Soltanpour, M.A. Tabatabai, C.T. Johnston, and M.E. Sumner, editors, Methods of soil analysis. Soil Science Society of America, Madison, WI.

Tuller, M., AND D. OR. 2004. Retention of water in soil and the soil water characteristic curve. Encyclopedia of Soils in the Environment 4:278-289.

WALCK, J.L., J.M. BASKIN, AND C.C. BASKIN. 2008. A comparative study of the seed germination biology of a narrow endemic and two geographically-widespread species of Solidago (Asteraceae). 4. Role of soil moisture in regulating germination. Seed Science Research 7:303-309.

WALKLEY, A., AND I.A. BLACK. 1934. An examination of the Degtjareff method for determining soil organic matter and a proposed modification of the chromic acid titration method. Soil Science 37:29-38.

WANG, J., H. WANG, Y. CAO, Z. BAI, AND Q. QIN. 2016. Effects of soil and topographic factors on vegetation restoration in opencast coal mine dumps located in a loess area. Scientific Reports 6:22058.

WEst, N.E. 1983. Western Intermountain sagebrush steppe. Pages 351-374 in N.E. West, editor, Temperate deserts and semi-deserts. Elsevier, Amsterdam.

WEST, N.E. 1988. Intermountain deserts, shrub steppes, and woodlands. Pages 209-230 in M.G. Barbour and
W.D. Billings, editors, North American terrestrial vegetation. Cambridge University Press, New York, NY.

Wilder, L.E., K.E. Veblen, K.G. Gunnell, and T.A. Monaco. 2018. Influence of fire and mechanical sagebrush reduction treatments on restoration seedings in Utah, United States. Restoration Ecology. https://doi.org/10.1111/rec.12860

Williams, J.R., L.R. Morris, K.L. Gunnell, J.J. JohanSON, AND T.A. MONACO. 2017. Variation in sagebrush communities historically seeded with crested wheatgrass in the eastern Great Basin. Rangeland Ecology and Management 70:683-690.

Wisdom, M.J., And J.C. Chambers. 2009. A landscape approach for ecologically based management of Great Basin shrublands. Restoration Ecology 17: 740-749.

Wuest, S.B., AND L.K. Lutcher. 2013. Soil water potential requirement for germination of winter wheat. Soil Science Society of America Journal 77:279-283.

Yacoubi, R., C. Job, M. Belghazi, W. Chaibi, and D. Job. 2011. Toward characterizing seed vigor in alfalfa through proteomic analysis of germination and priming. Journal of Proteome Research 10:3891-3903.

Young, J.A., R.A. Evans, And D. PalmQuist. 1990. Soil surface characteristics and emergence of big sagebrush seedlings. Journal of Range Management 43: 358-367.

Zhu, Y., X. Yang, C.C. Baskin, J.M. Baskin, M. Dong, AND Z. Huang. 2014. Effects of amount and frequency of precipitation and sand burial on seed germination, seedling emergence and survival of the dune grass Leymus secalinus in semiarid China. Plant and Soil 374:399-409.

Received 9 January 2018 Revised 21 November 2018 Accepted 31 December 2018 Published online 11 July 2019 
Copyright of Western North American Naturalist is the property of Monte L. Bean Life Science Museum and its content may not be copied or emailed to multiple sites or posted to a listserv without the copyright holder's express written permission. However, users may print, download, or email articles for individual use. 